\title{
CORRIGENDUM
}

\section{JNK1 controls adult hippocampal neurogenesis and imposes cell-autonomous control of anxiety behaviour from the neurogenic niche}

H Mohammad, F Marchisella, S Ortega-Martinez, P Hollos, K Eerola, E Komulainen, N Kulesskaya, E Freemantle, V Fagerholm, E Savontous, H Rauvala, BD Peterson, H van Praag and ET Coffey

Molecular Psychiatry (2018) 23, 487; doi:10.1038/mp.2017.21; published online 14 February 2017

Correction to: Molecular Psychiatry advance online publication, 15 November 2016; doi:10.1038/mp.2016.203

The 10th author's name was presented incorrectly. It should have been listed as E Savontaus. (c) (i) $(-)$ This work is licensed under a Creative Commons AttributionNonCommercial-NoDerivs 4.0 International License. The images or other third party material in this article are included in the article's Creative Commons license, unless indicated otherwise in the credit line; if the material is not included under the Creative Commons license, users will need to obtain permission from the license holder to reproduce the material. To view a copy of this license, visit http:// creativecommons.org/licenses/by-nc-nd/4.0/

(c) The Author(s) 2018 